\title{
Research \\ Social-Ecological Collapse: TURF Governance in the Context of Highly Variable Resources in Chile
}

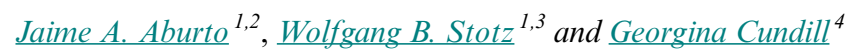

\begin{abstract}
In Chile, a Territorial User Rights for Fisheries system was developed to manage benthic fisheries. This system is referred to as Management Areas for the Exploitation of Benthic Resources. Management areas involved a shift from top-down control by governments to comanagement. We have analyzed the effects of a highly variable fishery, characterized by boom-and-bust cycles, on the governance of local institutions designed for resource management. We focused on a case study in north central Chile, in which the surf clam fishery experienced high levels of variability when the fishery was in an open access system. The management areas were established for the fishery in 1999. As a result, a set of rules for the fishery were created and enforced by fishers and local fishery authorities. Despite intense efforts on the part of all stakeholders, the fishery collapsed after three years of management area policy. This approach has been shown to be an effective management option for other species; however, for resources with boom-and-bust cycles, it is important to understand the response pattern of users confronting this spatial and temporal variability before the establishment of territorial user rights. Defining the appropriate spatial scale of the territorial rights could allow fishers to switch among different surf clam beds to maintain their livelihood and support the sustainability of local institutions for resource management.
\end{abstract}

Key Words: governance; management area; small-scale fishery; social-ecological; TURF

\section{INTRODUCTION}

Governance has traditionally been related to governments and what they do. Governance is, however, more complex (Jentoft and Chuenpagdee 2009) and refers to the structures, processes, rules, and traditions that shape individual and collective actions by which societies share power and make decisions (Lebel et al. 2006, Jentoft and Chuenpagdee 2009, Cundill and Fabricius 2010). Ecosystem governance is intrinsically difficult because both human societies and the natural environment are characterized by complex dynamics, including natural variations, scale dependencies, and associated uncertainties (Bodin and Crona 2009, Ostrom 2009). Dietz et al. (2003) have pointed out that successful commons governance is easier to achieve when (1) the use of resources can be monitored by community members at low cost; (2) changes in resources, user populations, technology, and other economic and social factors take place at moderate rates; (3) community members maintain direct communications and increase their trust of one another; (4) outsiders can be excluded from using the resource at relatively low cost; and (5) users are able to monitor and enforce their collectively designed agreements themselves. These characteristics illustrate the importance of considering governance at all scales, but particularly at the local scale where day-to-day decision making takes place and where governance ultimately succeeds or fails (Jentoft and Chuenpagdee 2009).

Accordingly, a great deal of research effort has been focused on defining the characteristics of social systems that are required for effective common pool resource governance. This has, however, come at the expense of understanding the implications of the nature of the ecological systems that these governance arrangements are intended to manage. Analysts have suggested, for example, that when institutions are well matched to the biophysical scale, and rate of ecological change, in which they are embedded, the probability of successful common pool resource governance increases (Cumming et al. 2006, Basurto and Coleman 2010). We reflect on governance experiences with a highly variable small-scale fishery that is characterized by boomand-bust cycles that have been out of kilter with the rate at which governance systems have been able to respond. We provide a descriptive account of a surf clam (Mesodesma donacium) fishery documented by Aburto and Stotz (2013) in which a well-managed, enforced, and regulated fishery under a comanagement regime failed. We analyze this case study through a social-ecological system (SES) lens and develop some hypotheses about effective fisheries governance under similar levels of ecological variability.

\section{Setting the scene: the challenge of fisheries governance}

Even in seemingly ideal cases, fisheries governance has often been unsuccessful (Beddington et al. 2007). Frequently cited reasons for governance failures in fisheries include the open access nature of many fisheries (Pauly et al. 1998), the opportunistic nature of many fishers and the impact of market forces on this behavior (Defeo and Castilla 1998), inappropriate approaches to governance that do not allow sufficient autonomy at the local level, and lack of incentives for conservation (Berkes et al. 2006). However, fisheries are highly complex SESs, characterized by high levels of uncertainty about the size and dynamics of fish populations and the natural variability of resources (de la TorreCastro and Lindström 2010). These ecological characteristics contribute to the crisis in fisheries as much as the previously cited reasons for governance failure.

The fisheries crisis has been widely documented for industrial fisheries, and there is growing recognition of a crisis in small-scale artisanal fisheries of benthic resources in particular (Allison and Ellis 2001, Orensanz et al. 2005). In benthic marine invertebrates, the high stock variability stems from recruitment, which is highly variable at different spatial and temporal scales (Lima et al. 2000, Aburto and Stotz 2013), and which depends on connectivity among metapopulations (Olivares 2005, Crowder and Norse 2008).

For benthic marine resources, spatially explicit management strategies, such as Territorial User Rights for Fisheries (TURF),

\footnotetext{
${ }^{1}$ Universidad Católica del Norte, Facultad de Ciencias del Mar, ${ }^{2}$ Programa de Doctorado en Biología y Ecología Aplicada (BEA), ${ }^{3}$ Centro de Estudios Avanzados en Zonas Áridas, ${ }^{4}$ Department of Environmental Science, Rhodes University
} 
has proved to be an effective alternative (Hilborn et al. 2005b, Gelcich et al. 2010). However, implementing a TURF system requires the development of new governance systems and incentives for management. In particular, a TURF system requires a shift from top-down centralized control to some form of collaborative (co-)management between resource users and the government (Pomeroy 1995).

\section{Governance transformation in benthic small-scale fisheries: the case of Chile}

In Chile, a TURF system has been developed to manage benthic fisheries. This has involved a shift from top-down control by governments to comanagement (Schumann 2007, Gelcich et al. 2010). This system is referred to as Management Areas for the Exploitation of Benthic Resources (AMERB). AMERBs were originally created in the 1990 s to deal with a crisis in the smallscale fishery of the snail (Concholepas concholepas), referred to locally as "loco" (Stotz 1997, Orensanz and Jamieson 1998, Castilla and Defeo 2001). The AMERB system assigns exclusive fishing rights for the exploitation of benthic resources to legally constituted fishers' organizations in defined coastal stretches. Chile has led the way with the implementation of a contemporary TURF as a de novo system at a large scale (Aburto et al. 2013). Officially, as of March 2013, there were 773 TURFs decreed with a total of 114,247 ha. Of these, 512 are decreed and assigned to an organization, with a total of 74,216 ha of coastline under TURF regimes (SUBPESCA 2013).

The initial success of AMERBs (Stotz 1997, Gelcich et al. 2010, San Martín et al. 2010) and the strong encouragement by the government (Meltzoff et al. 2002) inspired a mass replication of the management strategy along the Chilean coast and to different kinds of benthic resources. This occurred without a consideration of the characteristics of the ecological systems in which the approach was implemented. Currently, about 27 benthic species are managed under the AMERB system (Aburto et al. 2013). Among the resources managed through the AMERB system in Chile is the surf clam, known as "macha." Fluctuations in landings of surf clams are a common feature of these fisheries worldwide (McLachlan et al. 1996), making the sustainability of this fishery difficult to achieve (Ortega et al. 2012). This variability reflects fluctuations in the population size, which is related to highly variable levels of recruitment and mortality (Defeo and de Alava 1995, McLachlan et al. 1996).

$M$. donacium is the only sandy beach resource in Chile that has been intensively exploited throughout its distribution range, along a coastline of approximately $3000 \mathrm{~km}$ (Fernandez et al. 2000). The intensive fishery that has developed around this resource has shown large temporal and spatial fluctuations in its landings, often interpreted as fishers serially depleting stocks throughout the country (Thiel et al. 2007). Similar to early fishing communities, before AD 1500, modern fishers traveled along the coast following the densest populations of surf clams. When local stocks disappeared, they moved to a new location (Aburto and Stotz 2013). Since 1997, most of the surf clam beds have been managed through the AMERB system, preventing the migration of fishers between different surf clam beds. However, in 1997-1998, an El Niño event wiped out the majority of the surf clam population from Arica $\left(18^{\circ} 20^{\prime} \mathrm{S}\right)$ to the central coast of Chile, including Coquimbo $\left(29^{\circ} 55^{\prime} \mathrm{S}\right)$, leaving some minor populations in between (Riascos et al. 2009). However, despite the socioeconomic importance of the resource, no analyses have been conducted to assess the effects of this event on the local institutions designed for surf clam management. It is interesting to highlight that most of the surf clam AMERBs in Chile have failed. Since 1997, 23 AMERBs have been requested for $M$. donacium; however, at present just 3 AMERBs are operating (Fig. 1A).

An example of how a failure of an AMERB has played out in practice can be found in Tongoy Bay, in north central Chile. This fishery experienced high levels of variability prior to AMERB, when the fishery was characterized by an open access system. The AMERB was established for the fishery in 1999. As a result of AMERB implementation, the fishery was regulated with conservative quotas and frequent direct assessments. However, despite intense efforts on the part of all role players, from local fishers to local government authorities and local researchers, the Tongoy Bay surf clam fishery experienced a collapse, and the fishery stopped altogether after three years of AMERB policy (Aburto and Stotz 2013). We use the term "collapse" to refer to a situation in which a fishery system fundamentally changes because of a combination of severe harvest declines, resource depletion, and the failure of governance mechanisms to either prevent such depletion or to continue functioning in the face of these ecological shifts. The main reason for the resource decline was the lack of successive recruitment, which may be linked to the metapopulation structure and dynamics of the broader Coquimbo Bay system (Aburto and Stotz 2013), but it was also attributable to the high natural mortality of surf clams. Even though the surf clam bed did not disappear completely, the low density made the fishery unattractive, causing the loss of incentives for resource care and the abandonment of the AMERB (Aburto and Stotz 2013). Reflecting on the effects of the fishery collapse, attributable to natural resource variability, and its effects on local governance reveals some lessons that may be of use in designing more appropriate governance approaches suited to highly variable resources. We report on an effort to analyze the role played by resource variability in the governance scheme developed around this surf clam fishery. This represents somewhat of a departure from typical governance assessments that tend to ask questions about the impact of economic incentives or governance design. We seek to explore the implications of governance design and the nature of the ecological system simultaneously. We assessed the extent to which the governance transformation that occurred in Tongoy Bay complied with generally accepted preconditions for effective commons governance (Dietz et al. 2003). Toward this end, we describe the governance transformation in two different periods, prior to AMERB, i.e., open access, and during the AMERB system when rules were created and enforced. We then assess the causes of, and impact of, resource collapse on the governance system developed around AMERB.

Study area and brief introduction to Tongoy fisher organization Tongoy Bay $\left(30^{\circ} 15^{\prime} \mathrm{S}, 70^{\circ} 30^{\prime} \mathrm{W}\right)$ is located in north central Chile (Fig. 1) and contains an urban caleta. A caleta is a small-scale fishing port, usually associated with a protected coastal bay, i.e., the caleta, which allows fishers to safely land and/or anchor their fishing boats. The term refers to the entire setting, including the bay, the pier when there is one, the boat yard, and the huts or 
Fig. 1. Study site, (A) Circle with striped pattern represents the administrative region in Chile (see Chile map) in which a surf clam fishery was developed in the period 1960-1998. The white circles with numbers represent the administrative region in which surf clam AMERBs were requested, the numbers represent the number of AMERBs granted. The black circle represents the AMERBs that are currently functioning. The black zone in the map represents the general location of the study site. (B) Bay system of Coquimbo region, main sandy beaches are shown with black circles. (C) Location of Tongoy AMERB, the black polygon represents the approximated distribution of the surf clam bed. (D) and (E) surf clam fishers working as hand gatherers (photos from Coquimbo Bay)
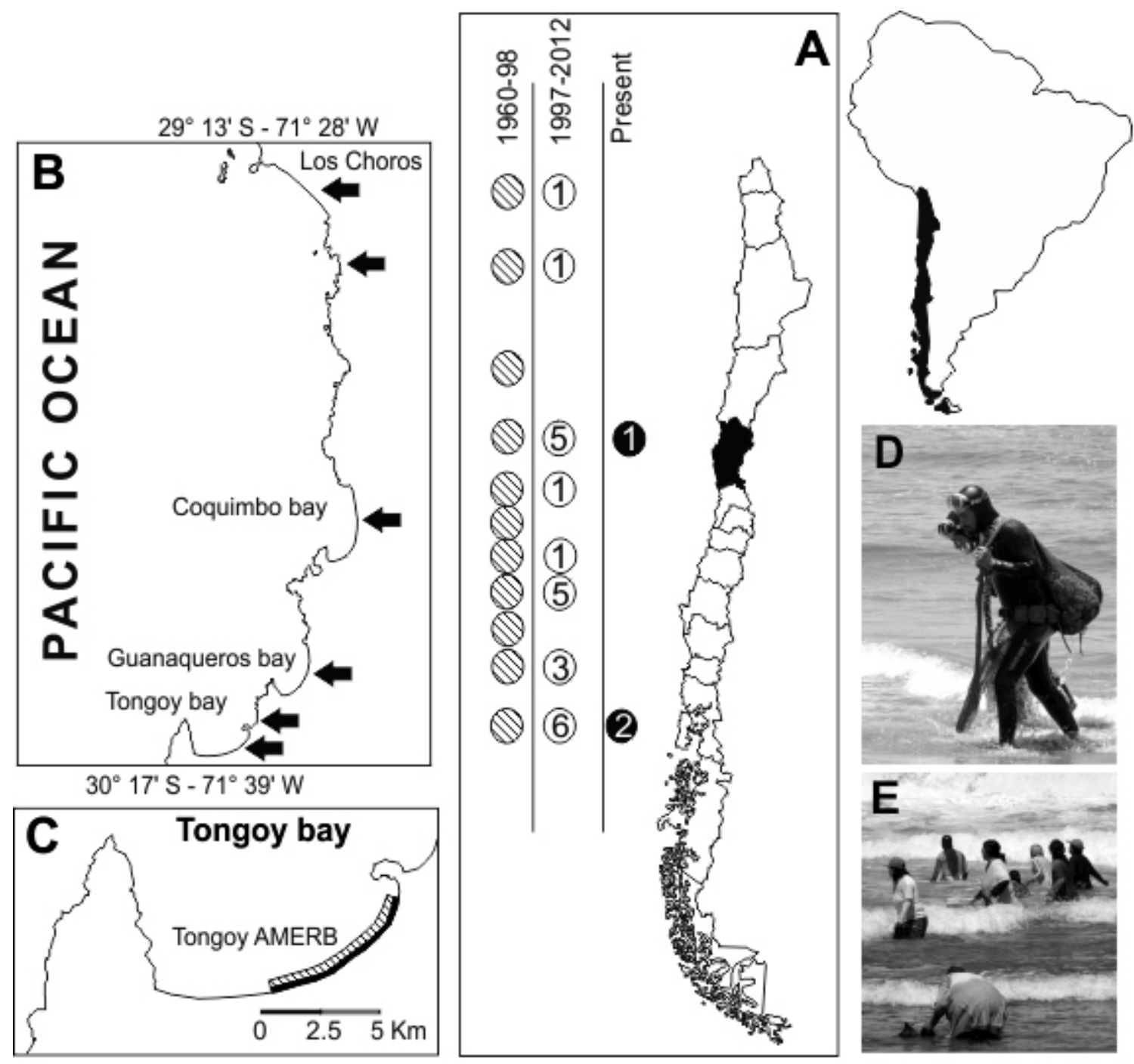

sheds in which fishers camp or the associated houses or community in which the fishers live. In the Tongoy caleta, there are 654 registered fishers. Of these, 253 are grouped into a guild association. In the past, a subgroup of this guild association, both men and women, worked exclusively on the surf clam fishery. The surf clam fishers operated as hand gatherers in the surf zone during low tides (Fig. 1C, D). This subgroup belonged to the larger fishers' guild association and did not have its own organization specifically concerned with the surf clam fishery.
However, in 1999, this group organized itself to take part in the AMERB but remained part of the Tongoy guild association.

\section{METHODS}

This analysis is based on a combination of three sources of data: landing data that were collected by the state prior to AMERB, data collected by the authors through direct assessment of surf clam populations during the AMERB, and reflections on collaborative work undertaken with surf clam fishers during the 
AMERB period. By combining these different sources of data, we were able to assess changes in this fishery, and to link this to changes in governance, over a period of 25 years.

\section{Landing data}

Landing data from the period of open access, prior to the AMERB, were obtained from the Department of Statistical Fisheries Research, which is part of the National Fishery Service, i.e., Servicio Nacional de Pesca (Sernapesca). Landing data were available for the period January 1985 to April 1999. Accurate data on surf clam landings from the AMERB were obtained from the surf clam fishers subgroup between July 1999 and December 2001. The group developed its own database to monitor landings and improve the commercialization process. Landing data from the open access period and in the AMERB period were recorded monthly. The landing data collected by both the fishers and the state were for yield. After 2001, there was no information about landings until 2009-2010, when sporadic landings were declared by the fishers involved in the harvests.

\section{Direct assessment}

Evaluations of surf clam banks were conducted regularly from April 1998 to November 2004. During this period, direct assessments were conducted collaboratively with the surf clam fishers. After that, direct assessment did not occur until 2007 because of a lack of participation of fishers. From March 2007 to February 2010, direct collaborative assessments were once again conducted because the leaders of the Tongoy guild association felt concerned that they might lose their AMERB if they did not conduct the required assessments.

The sampling design consisted of 16 transects, $500 \mathrm{~m}$ apart from each other and extending perpendicular to the shoreline, covering the full length of the AMERB. Each transect had three sampling stations and crossed the entire depth distribution of the surf clam. To facilitate the assistance of fishers in the assessments, we defined each station according to three water depths. The first samples were taken with the water at ankle level $(10-20 \mathrm{~cm})$, the second at knee level $(\sim 50 \mathrm{~cm})$, and the third at chest level $(\sim 1.5 \mathrm{~m})$. Three replicates were conducted in each sampling station. Samples were collected with a $0.05-\mathrm{m}^{2}$ core and a sieve with $1-\mathrm{mm}$ mesh. Surf clams collected were weighed and measured. Also, subtidal surveys were conducted to ascertain the presence of surf clams in this habitat. The density estimation was assessed for the whole surf clam population.

\section{Direct engagement with fishermen and authorities}

Two of the authors, J. A. Aburto and W. B. Stotz, interacted and worked directly with the fishers over a period of four years and therefore observed through participatory observation many of the social dynamics that took place during the implementation of the AMERB. The Tongoy guild association, the surf clam fishers, the local office of Sernapesca, and the Chilean navy were engaged by the authors to work collaboratively toward the design of a participatory management plan for the surf clam fishery. Topics covered in these engagements therefore ranged from surf clam availability and landings to governance and decision making. A series of meetings was held with the leaders of the Tongoy guild association, starting in 1998, which was prior to the implementation of AMERB. The interactions included participatory workshops to design the management plan and its operation and to train in sampling methods. In addition, regular meetings were held for the purpose of monitoring and analyzing the fishery over time.

\section{RESULTS}

\section{The surf clam fishery at Tongoy prior to AMERB}

Historically, landings of surf clams have been highly variable in Tongoy (Fig. 2A). In periods in which surf clams were highly abundant, fishers from different caletas and people from Tongoy who were not traditional fishers became involved in the surf clam fishery in Tongoy. However, when surf clams became scarce, which occurred in the period between 1995 and 1999, when landings were very low (Fig. 2A), some of the surf clam fishers migrated to the surrounding beaches to continue their involvement in the surf clam fishery. This was a common characteristic of this fishery prior to AMERBs in the bay system of Coquimbo (Fig. 1), in which surf clam fishers from different caletas moved between different surf clam beds, sometimes camping on those beaches for a period. There is not an official register of surf clam fishers who worked in Tongoy Bay in the open access period, 1985-1999 (Fig. 2). Those surf clam fishers worked the fishery individually, without collaboration among them or any formal organization. Because they worked alone, they also sold their products to a large number of middlemen. The price of the resource was determined by the middlemen. By contrast, during the AMERB period, the surf clam fishers organized themselves and decided the price of the resource collectively, controlling the market. Also, it was common that the middlemen gave loans to fishers and in this way forced fishers to sell surf clams to them alone to pay back the loans.

In 1998, a strong El Niño Southern Oscillation (ENSO) event caused intense rainfall in central northern Chile. At the local level, this resulted in the Elqui River flooding the main surf clam bed of the region, located in Coquimbo Bay, $40 \mathrm{~km}$ north of Tongoy (Fig. 1B). This resulted in the surf clam fishery collapsing in the bay. However, the fishery continued in Tongoy and Los Choros beach, the latter located approximately $100 \mathrm{~km}$ north of Coquimbo Bay (Fig. 1B). As a result of flooding, a large number of surf clam fishers from Coquimbo Bay migrated to Tongoy Bay. According to the fishers, during 1998-1999, about 200 people, from different caletas, mainly from Coquimbo and Tongoy, were involved in surf clam extraction in the Tongoy Bay bed. There was no control over catches or the size of surf clams harvested. In addition, the direct assessment showed that the population of surf clams over minimum catch size was only $3.3 \%$, indicating that the fishery was concentrated mostly on juveniles. The leaders of the Tongoy guild association, concerned about the uncontrolled situation in the future AMERB, and without a previous agreement with the surf clam fishers, who belong to the organization, decided to ask the local Sernapesca and the Chilean navy to enforce the AMERB regulations, which do not allow harvest while a management plan is not approved. With this decision, surf clam extraction in the Tongoy AMERB was banned in May 1999.

\section{The creation of the Tongoy AMERB}

The AMERB process involves a series of steps that fisher organizations must comply with to be permitted to manage an area (Fig. 3). In October 1997, the Undersecretary of Fisheries, i.e., Subsecretaría de Pesca, enacted the available area decree of the Tongoy AMERB. This meant that the fishers' organization could apply to obtain an AMERB in that coastal sector. For the application, the organization had to submit a baseline study of the area, called Estudio de Situación Base del Área (ESBA), and a proposal for a management plan for the desired resources in the 
area. The guild association submitted the ESBA proposal in August 1998; however, the harvest in the Tongoy AMERB did not stop, as the law requires, and the harvest continued by fishers from both Tongoy and other caletas, mainly from Coquimbo Bay. The organization, with the advice of Universidad Católica del Norte (UCN), presented the results of the direct assessment and the management plan in November 1999. It was approved by the fisheries authorities in March 2000.

Fig. 2. (A) Landings of surf clam (solid line) in open access and AMERB ((Management Areas for the Exploitation of Benthic Resources)) periods (main Y-axis). Symbols represent different milestones in Tongoy AMERB process (black arrows) Available area decree, (black star) ESBA (Estudio de Situación Base del Área) proposal, (white star) ESBA result and management plan for Undersecretary of Fishery report, (white cross) socialecological system collapse. The gray zone in the main graph (A) represents the AMERB surf clam fishery with a quota regime. (B) Bar graph represents the surf clam density (ind. m-2) estimated in the AMERB direct assessments for the whole surf clam population, lines are the standard deviation. (C) Bars represent the total population estimated for the AMERB in each direct assessment. The white zone represents the population fraction below the Minimum Catch Length (MCL $=60 \mathrm{~mm}$ ). The black zone of the bar represents the population fraction over MCL. The rectangle above the chart represents the effort ( $\mathrm{N}^{\circ}$ of fishers) during different periods in the surf clam fishery in Tongoy bay.

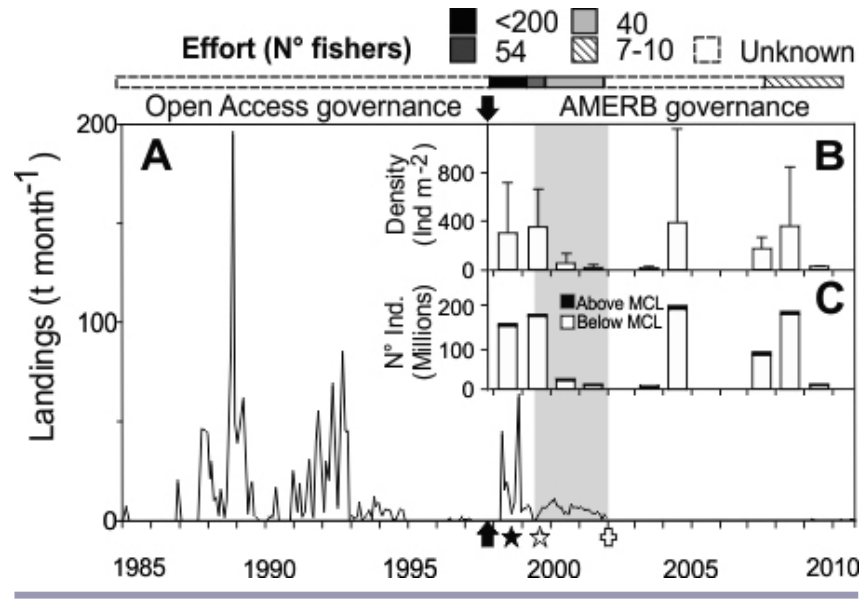

\section{From open access to AMERB}

The surf clam ban in Tongoy Bay caused serious socioeconomic problems for surf clam fishers, who felt excluded from the decision to close the fishery. As a result, in conjunction with the ban, surf clam fishers organized themselves to act collectively to find solutions to their socioeconomic problems. The emergent organization arranged several meetings with the leaders of the guild association and with the university to find a solution to the social crisis. Meanwhile, the direct assessment of surf clams for the baseline study, in April 1999, showed a strong recruitment of surf clams inside the limits of the future AMERB (Fig. 2C). This allowed for projections of potential future harvests.
Fig. 3. Flow diagram of AMERB (Management Areas for the Exploitation of Benthic Resources) application process, bold numbers indicate the suggested time for each step ( $d=$ days $)$.

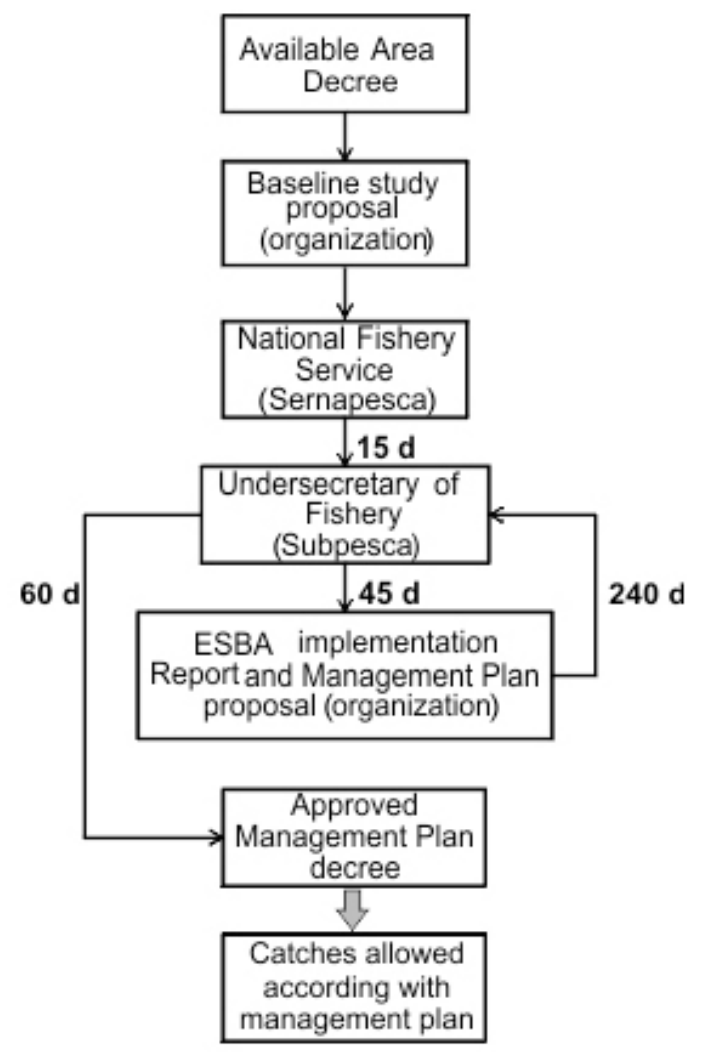

In this context, the good surf clam recruitment, the new social coordination among surf clam fishers, as demonstrated by the collaborative effort just described, and the AMERB policy, produced a "window of opportunity" (sensu Olsson et al. 2006) to move the SES onto a more desirable trajectory through improved governance. Accordingly, at the local level, with the stakeholders involved in the surf clam fishery, i.e., guild association leaders, surf clam fisher leaders, Sernapesca, the Chilean navy, and the UCN fishery (Fig. 4), a collaborative effort to establish an emergency management plan was initiated. The management plan came into action in July 1999, despite the fact that the formal management plan was not yet approved by the Undersecretary of Fisheries.

The reason for making the decision at the local level was because the bureaucracy involved in the AMERB process from local to national levels is time consuming (Fig. 4). The needs of the Tongoy surf clam fishers, combined with the reality of poaching by outsiders, made the implementation of the emergency management plan urgent. For this reason, the collaborative group decided to implement the management plan, despite the fact that this action was not allowed by the AMERB policy but fulfilled local social needs. Surf clam fishers respond quickly to environmental and socioeconomic drivers, and in this context, 
local institutions were able to react in the time frame of hours to days, in the case of fishers, or in weeks in the case of direct assessment and fishery/quota recommendations (Fig. 4). In this sense, given the particular social-ecological conditions of the system, i.e., poaching, a group of emergent fishers, good surf clam recruitment, resource variability, and so forth, the success of a management plan was possible only because the decisions were made in the context of local-level time frames for responses.

Fig. 4. The collaborative group (gray box) and the time scale of responses of different institutions (from local to national level) involved in the AMERB (Management Areas for the Exploitation of Benthic Resources) process and decision making.

\section{Collaborative group}

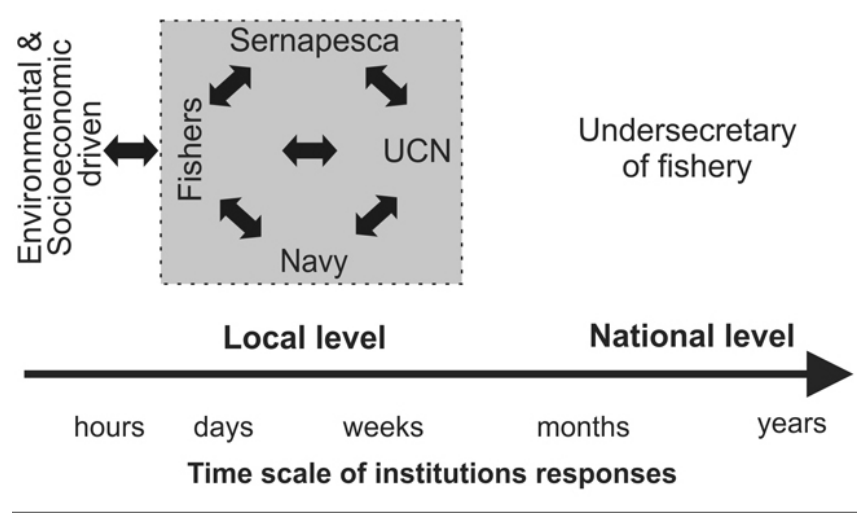

The social-ecological considerations of the management plan The management plan had both socioeconomic and biological reference points. With the socioeconomic reference point, the group developed a minimum quota, in which fishers earn at least US\$185 per month, which aligned with the minimum official national salary in 1999 and was also similar to the income of fishers working in other fisheries. With this reference point, the collaborative group sought to ensure that surf clam fishers had a stable and predictable income that would lead to stronger commitment to the management plan by the fishers. The minimum quota was previously discussed with fishers, who were in agreement with this socioeconomic reference point.

With the biological reference point, the group developed a maximum quota, in which the group decided, based on the direct assessment, that catches could be maintained for at least 36 months, without depending on new recruitment. This estimation was corrected and re-estimated once a year, based on the results of the annual direct assessment. The direct assessment to adjust the quota was conducted once a year, and several direct assessments were conducted in between to monitor the entire surf clam bed and/or specific exploited patches (see Aburto and Stotz 2013 for further details). The fishery started with 40 surf clam fishers registered in the surf clam fishers' organization; nevertheless, when the surf clam price increased, the surf clam fishers' group decided to incorporate more fishers, extending the benefits of the fishery to 54 people (Fig. 2).
For the operation of the management plan, each of the stakeholder groups assumed responsibilities. For example, local authorities from the Tongoy office of Sernapesca and the navy assumed responsibility for preventing poaching. The UCN agreed to conduct direct assessments working closely with the fishers. Meanwhile, the surf clam fishers agreed to take responsibility for developing a surveillance plan for the AMERB, to take control of catches, i.e., in terms of size and amount, and to oversee the fishery with a special commission. Fishers agreed to work only on established days and hours. The organization established that all surf clam fishers must work at the same time, during low tide and in specific patches inside the surf clam bed based on the biomass availability, determined by the UCN's direct assessment. In addition, they used a special identification, made by themselves, that identified them as surf clam fishers of the Tongoy AMERB. With this, they facilitated the supervision of Sernapesca and the navy to tackle poaching from other fishers. In addition, the fishery became restricted only to surf clam fishers from Tongoy. This involved a decrease in fisher numbers and controlled access, and it prevented new fishers from entering the area.

\section{The governance transformation and the effects of the management plan}

A series of positive outcomes was observed in the initial months following the formalization of the fishery (Table 1). The surf clam fishers developed a strong organization that was able to take control of the fishery, with internal control of landings and compliance with the quotas estimated by direct assessment. Surf clam fishers implemented an effective surveillance plan, with patrols over 24 hours a day. They bought two four-wheel-drive vehicles for this purpose. They also improved commercialization of the resource by auctioning the harvest to the best paying customer. With this, the organization worked with only one middleman, increasing the surf clam price from less than US\$1.00 to US $\$ 2.50$ per kilogram in a few months.

The new common extraction system ensured equity. The monthly quota was divided by the fishers into daily quotas, and each daily quota was divided among all members. Nevertheless, those surf clam fishers that could not fulfill the quota (mainly women, older people, or sick fishers) were helped by other fishers; in this way, each member of the organization got the same income. Surf clam fishers developed a series of internal rules and regulations to support effective monitoring and rule enforcement. The organization also strengthened their social networks with frequent communication among different stakeholders: local, regional, and national fishery authorities; the Chilean navy; leaders of the Tongoy guild association; the UCN; the municipality; and traders. With surveillance and enforcement, the surf clam fishers successfully decreased poaching in the AMERB. With the implementation of the AMERB, alongside the growing organization among fishers, and collaboration with various partners, a more organized governance system in line with international thinking about commons governance emerged (Table 1)

From September 2000, a constant decrease in landings was experienced, with the fishery collapsing in December 2001 (Fig. 2A). However, further north in Coquimbo Bay (Fig. 1B), the fishery recovered after the resource collapsed, and approximately 400 fishers began to harvest under a new AMERB created in this 
Table 1. Characteristics of successful commons governance (sensu Dietz et al. 2003) and the fishery characteristics observed in the preAMERB (Management Areas for the Exploitation of Benthic Resources) fishery and the governance transformation after AMERB implementation.

\begin{tabular}{|c|c|c|c|}
\hline $\begin{array}{l}\text { Characteristics for } \\
\text { successful commons } \\
\text { governance (Dietz et al. } \\
\text { 2003) }\end{array}$ & $\begin{array}{l}\text { Pre-AMERB fishery } \\
\text { characteristics }\end{array}$ & $\begin{array}{l}\text { Characteristics of the governance } \\
\text { transformation in Tongoy surf clam } \\
\text { fishery. }\end{array}$ & $\begin{array}{l}\text { Characteristics after fishery and } \\
\text { governance collpase }\end{array}$ \\
\hline $\begin{array}{l}\text { The use of resources can be } \\
\text { monitored by community } \\
\text { members at low cost. }\end{array}$ & $\begin{array}{l}\text { Users did not monitor the } \\
\text { resource }\end{array}$ & $\begin{array}{l}\text { Users monitored the resource; the } \\
\text { cost was subsidized by the } \\
\text { government. }\end{array}$ & $\begin{array}{l}\text { Users did not monitor the } \\
\text { resource anymore }\end{array}$ \\
\hline $\begin{array}{l}\text { Changes in resources, user } \\
\text { populations, technology, and } \\
\text { other economic and social } \\
\text { factors take place at } \\
\text { moderate rates. }\end{array}$ & $\begin{array}{l}\text { The change rate of resources } \\
\text { was high, fishers responded } \\
\text { to these fluctuations by } \\
\text { migrating or switching } \\
\text { among different activities }\end{array}$ & $\begin{array}{l}\text { The change rate of resource was } \\
\text { high, fishers responded to the } \\
\text { resource change dissolving their } \\
\text { organization. }\end{array}$ & $\begin{array}{l}\text { Fisher adjusted its number to } \\
\text { the bank production, as } \\
\text { happened in the fishery in the } \\
\text { past. }\end{array}$ \\
\hline $\begin{array}{l}\text { Community members } \\
\text { maintain direct } \\
\text { communications and } \\
\text { increase their trust of one } \\
\text { another. }\end{array}$ & $\begin{array}{l}\text { There was no previous } \\
\text { organization or sense of } \\
\text { "community" }\end{array}$ & $\begin{array}{l}\text { Surf clam fishers developed a new } \\
\text { institution with frequent meetings. } \\
\text { Different roles were assigned by } \\
\text { fishers themselves. }\end{array}$ & $\begin{array}{l}\text { The organization was dissolved. } \\
\text { Any collective action. }\end{array}$ \\
\hline $\begin{array}{l}\text { Outsiders can be excluded } \\
\text { from using the resource at } \\
\text { relatively low cost. }\end{array}$ & $\begin{array}{l}\text { There was open access to the } \\
\text { surf clam fishery on the } \\
\text { beach. Anyone could } \\
\text { harvest the resource }\end{array}$ & $\begin{array}{l}\text { Outsiders were (mostly) excluded } \\
\text { and poaching was prevented by } \\
\text { fisher patrols with the cooperation } \\
\text { of Chilean navy and National } \\
\text { Fisheries Service (Sernapesca). }\end{array}$ & $\begin{array}{l}\text { The area was still under } \\
\text { comanagement regime, but } \\
\text { without control or patrol to } \\
\text { exclude people that did not } \\
\text { belong to the organization }\end{array}$ \\
\hline $\begin{array}{l}\text { Users are able to monitor } \\
\text { and enforce their collectively } \\
\text { designed agreements } \\
\text { themselves. }\end{array}$ & $\begin{array}{l}\text { There were no rules in the } \\
\text { fishery, besides those of } \\
\text { authorities at national level } \\
\text { (minimum size of capture) }\end{array}$ & $\begin{array}{l}\text { Fishers created their own operating } \\
\text { rules; internal commissions } \\
\text { monitored the compliance with the } \\
\text { agreements. }\end{array}$ & $\begin{array}{l}\text { There were no local rules in the } \\
\text { fishery }\end{array}$ \\
\hline
\end{tabular}

bed. Meanwhile, fishers in Tongoy no longer worked because the activity was uneconomical. After the surf clam biomass declined, the whole organization that had developed around the surf clam fishery in Tongoy experienced a crisis. Surf clam fishers stopped the surveillance and sold the four-wheel-drive trucks. The surf clam fishers' group was dissolved, and all activities in the AMERB were stopped. No registers were maintained for surf clam fishers working in the area or their catches. Most of the fishers changed to other economic activities. In 2004, direct assessment in the AMERB showed a recovery of the surf clam bed (Fig. 2B, C); however, the social system that was developed in the AMERB before 2001 has never recovered. At present, according to fishers, an estimated number of 7-10 fishers work sporadically in the surf clam fishery in the AMERB, but as they did in the past, before the AMERB implementation, and without collective action.

\section{DISCUSSION}

In our case study, the fluctuation in resource biomass had a strong effect on the institution developed for resource management. When the AMERB provided fishers with a harvestable resource, there was an incentive for fishermen to create and enforce their own rules, maintaining the functioning of the organization and creating democracy in resource management (Cinner et al. 2012a). However, when the resource abundance declined, the low density made the fishery unattractive (Aburto and Stotz 2013), the incentives were lost, and the governance institution was abandoned and did not recover even when the resource itself recovered.
Some scholars have noted that the key for successful management is the establishment of exclusive property rights, incentive-based management, the establishment of a set of rules intended to curb exploitation rates, and the development of appropriate institutions for governance (Hilborn et al. 2005a, Acheson 2006, Grafton et al. 2006, Cinner et al. 2012b). In line with this, Agrawal and Goyal (2001) indicate that individuals choose to participate in creating an institution after assessing the rewards and the cost of doing so. It has also been suggested that the creation of institutional arrangements and management regimes helps resource users allocate benefits equitably, over long time periods and with limited efficiency losses (Agrawal 2001). Ostrom (2009) has highlighted that the probability of self-organizing behavior among users is high when the expected benefits of resource management exceed the perceived cost of investing in better rules and norms. In our case study, though, even when secure property rights were granted, with clearly defined boundaries and an effective governance institution, with internal rules, graduated sanctions, and incentives, this was not enough to maintain a sustainable fishery. Incentives, in the form of harvestable biomass, appear to have been the key variable in this situation, and one that outweighed all others when the fishery collapsed. Social coordination requires incentives (Hilborn et al. 2005a, Grafton et al. 2006, Ostrom 2009), and if those incentives are not there, then we cannot expect fishers to invest their time in social coordination and in governance system development. This does not, however, explain why the governance institution failed to return even when the incentives to do so regenerated. 
It has been argued elsewhere that group size can have a direct relationship with successful collective action. Small groups are unable to monitor the resource, and thus no institution is worthwhile. On the other hand, large groups have problems because of free-riding effects (Agrawal and Goyal 2001). Moreover, strong leadership, individual or collective quotas, social cohesion, and protected areas have been highlighted as key factors for successful comanagement (Gutiérrez et al. 2011). In our case study, the institutional and governance loss did not appear to be strongly related to group size: There was strong commitment to the agreements, surf clam fishers were satisfied with the quota system and with their income, fishers never exceeded the monthly quotas (Aburto and Stotz 2013), an organized patrol to prevent poaching was conducted daily, and direct assessments were done collectively. Therefore, from a collective action and institutional viewpoint, the AMERB was functionally effective. This system also complied with the key factors described by Gutiérrez et al. (2011). The main cause of institutional and governance failure appears to have had its origins in the ecological characteristics of the resource in question. The irregular and unpredictable recruitment with high fluctuation of biomass over time (Aburto and Stotz 2013) made resource management much more difficult than standard governance texts would suggest. Biomass variability was correctly assessed in the projections, as shown by a strong correlation between projections and measured values in the bed (Aburto and Stotz 2013). In cases such as this, where biomass fluctuations are the norm, it seems that the cost of maintaining effective governance systems may be higher than the benefits over time, leading inexorably to SES collapse. Even though mass mortalities have been described for this resource (Riascos et al. 2009), and suggestions have been made that this may have swamped existing management measures (Ortega et al. 2012), this was not the case for $M$. donacium in Tongoy Bay. Although the population was decimated in Coquimbo with the ENSO in 1997-1998, the population in Tongoy was not affected.

The case of Tongoy Bay surf clam fishers complied with the generally accepted preconditions for effective commons governance outlined in the introduction (Dietz et al. 2003), except with regard to point (2), i.e., that changes in resources, user populations, technology, and other economic and social factors take place at moderate rates. We hypothesize that the high rate of change of the resource impacted significantly on the ability of the social system to develop and maintain governance systems. It is also interesting to note that when the resource recovered later, in 2004, the social system did not. There may also be psychological reasons for fishers giving up on highly demanding social coordination activities once failure has been experienced. Another more obvious reason for not recovering is that highly variable resources are too risky and users cannot depend on just one, highly variable, resource to support their livelihood, so fishers invest time in more reliable sources of income.

However, if historically the fishery adhered to boom-and-bust cycles, with fishers migrating among different surf clam beds or switching from different activities or fisheries, why did the surf clam fishers of Tongoy self-organize quickly in the first place? Agrawal and Goyal (2001) argue that the cost of institution formation can be low in cases where villages and settlements already exist, and this was the situation in Tongoy and therefore may have played a role. On the other hand, at the beginning of the AMERB process in Tongoy, based on the success of AMERB approaches for the loco fishery (Gelcich et al. 2010, San Martín et al. 2010, Aburto et al. 2013), Tongoy surf clam fishers assumed that the granting of property rights held the potential to secure a sustainable fishery. Simultaneously, Tongoy fishers felt threatened because the guild leaders excluded them from the fishery while fishers from other areas were harvesting the resource illegally. All of these factors, some negative push factors, others positive pull factors, resulted in Tongoy fishers feeling the need to self-organize to take control of the fishery. This might be explained by Ostrom's (2009) observation that when resource users observe scarcity in the resource base, they invest in self-organization. Agrawal and Goyal (2001) have suggested that individuals take into account both the marginal increase in the likelihood of institution formation and the payoffs from the subsequent activities of the institution. In our case study, it is possible that the cost of collective action and institution development exceeded its benefits, and for this reason, when the surf clam population recovered, the fishers did not organize again. We hypothesize that in this case fishers learned that managing the resource at the local scale was not effective and therefore reverted to historical use patterns when the resource recovered.

Although collective action and coordination seems to be a desirable condition for the governance of resources, our case study suggests that a lack of coordination is not always an undesirable state. In this case, it was a state that allowed individual fishers to switch quickly between alternatives to maintain their livelihoods. This dynamic response to resource fluctuations is a common characteristic in small-scale fisheries (Allison and Ellis 2001) and may in fact be compatible with both the social needs of fishers and the ecological features of highly variable resources such as the surf clam (Aburto and Stotz 2013).

\section{CONCLUSIONS}

The AMERB approach has been shown to be an effective management option for hard-bottom resources, such as locos. In these cases, this approach has increased the population biomass in most of the AMERBs (San Martín et al. 2010) and introduced important changes in the associated governance systems (Gelcich et al. 2010). However, in some cases, AMERB implementation can reduce management effectiveness as has been described by Gelcich et al. (2006), where the AMERB policy weakened and reduced the resilience of pre-existing traditional institutions that were developed for the bull-kelp (Durvillaea antarctica) management in the south of Chile.

With resources of high variability, such as surf clams, it remains important to study the resource dynamics at both the local scale and mesoscale and to learn from the traditional responses of users confronting this variability. It has been observed that when users struggle with unpredictability at a local scale, sometimes it might be more effective to organize at a larger scale to increase overall predictability (Ostrom 2009). In this context, a challenge for future research is to understand the spatial scale of resource variability, before the establishment of territorial user rights, as well as defining its appropriate spatial scale. Something similar has been proposed by Wilson (2006) who suggests a multiscale 
governance approach that starts at a local scale, but whose outer boundaries are defined by the spatial organization of the ecosystem. This kind of approach could allow fishers to switch among different surf clam beds to maintain their livelihood and the sustainability of local institutions for resource management. This represents a new spatial proposal for the current AMERB system, linking beds along the coast in an integrated system. This could allow migrations among different beds, as was used in the past, introducing spatial flexibility that allows fishers to deal with biomass fluctuations. However, this needs flexible regulations, allowing fishers to migrate, when circumstances make this necessary.

Responses to this article can be read online at: http://www.ecologyandsociety.org/issues/responses. $\mathrm{php} / 6145$

\section{Acknowledgments:}

J. A. Aburto acknowledges financial support from CONICYT, Programa de Formación de Capital Humano Avanzado, during the preparation of this manuscript. J. A. Aburto also acknowledges "Proyecto MECESUP UCN1104: Internacionalización del Programa de Doctorado en Biología y Ecología Aplicada." The manuscript is part of J. A. Aburto's Ph.D. thesis in applied biology and ecology (BEA) at Universidad Católica del Norte. The authors appreciate the valuable comments and suggestion of the anonymous reviewers.

\section{LITERATURE CITED}

Aburto, J., G. Gallardo, W. Stotz, C. Cerda, C. MondacaSchachermayer, and K. Vera. 2013. Territorial user rights for artisanal fisheries in Chile - intended and unintended outcomes. Ocean \& Coastal Management 71:284-295. http://dx.doi. org/10.1016/j.ocecoaman.2012.09.015

Aburto, J., and W. Stotz. 2013. Learning about TURFs and natural variability: failure of surf clam management in Chile. Ocean \& Coastal Management 71:88-98. http://dx.doi. org/10.1016/j.ocecoaman.2012.10.013

Acheson, J. M. 2006. Institutional failure in resource management. Annual Review of Anthropology 35:117-134. http:// dx.doi.org/10.1146/annurev.anthro.35.081705.123238

Agrawal, A. 2001. Common property institutions and sustainable governance of resources. World Development 29:1649-1672. http://dx.doi.org/10.1016/S0305-750X(01)00063-8

Agrawal, A., and S. Goyal. 2001. Group size and collective action: third-party monitoring in common-pool resources. Comparative Political Studies 34:63-93. http://dx.doi.org/10.1177/0010414001034001003

Allison, E. H., and F. Ellis. 2001. The livelihoods approach and management of small-scale fisheries. Marine Policy 25:377-388. http://dx.doi.org/10.1016/S0308-597X(01)00023-9

Basurto, X., and E. Coleman. 2010. Institutional and ecological interplay for successful self-governance of community-based fisheries. Ecological Economics 69:1094-1103. http://dx.doi. org/10.1016/j.ecolecon.2009.12.001
Beddington, J. R., D. J. Agnew, and C. W. Clark. 2007. Current problems in the management of marine fisheries. Science 316:1713-1716. http://dx.doi.org/10.1126/science.1137362

Berkes, F., T. P. Hughes, R. S. Steneck, J. A. Wilson, D. R. Bellwood, B. Crona, C. Folke, L. H. Gunderson, H. M. Leslie, J. Norberg, M. Nyström, P. Olsson, H. Österblom, M. Scheffer, and B. Worm. 2006. Globalization, roving bandits, and marine resources. Science 311:1557-1558. http://dx.doi.org/10.1126/ science. 1122804

Bodin, Ö., and B. I. Crona. 2009. The role of social networks in natural resource governance: what relational patterns make a difference? Global Environmental Change 19:366-374. http://dx. doi.org/10.1016/j.gloenvcha.2009.05.002

Castilla, J. C., and O. Defeo. 2001. Latin American benthic shellfisheries: emphasis on co-management and experimental practices. Reviews in Fish Biology and Fisheries 11:1-30. http://dx. doi.org/10.1023/A:1014235924952

Cinner, J. E., T. M. Daw, T. R. McClanahan, N. Muthiga, C. Abunge, S. Hamed, B. Mwaka, A. Rabearisoa, A. Wamukota, E. Fisher, and N. Jiddawi. 2012a. Transitions toward comanagement: the process of marine resource management devolution in three east African countries. Global Environmental Change 22:651-658. http://dx.doi.org/10.1016/j.gloenvcha.2012.03.002

Cinner, J. E., T. R. McClanahan, M. A. MacNeil, N. A. J. Graham, T. M. Daw, A. Mukminin, D. A. Feary, A. L. Rabearisoa, A. Wamukota, N. Jiddawi, S. J. Campbell, A. H. Baird, F. A. Januchowski-Hartley, S. Hamed, R. Lahari, T. Morove, and J. Kuange. 2012b. Comanagement of coral reef social-ecological systems. Proceedings of the National Academy of Sciences of the United States of America 109:5219-5222. http://dx.doi. org/10.1073/pnas.1121215109

Crowder, L., and E. Norse. 2008. Essential ecological insights for marine ecosystem-based management and marine spatial planning. Marine Policy 32:772-778. http://dx.doi.org/10.1016/j. marpol.2008.03.012

Cumming, G. S., D. H. M. Cumming, and C. L. Redman. 2006. Scale mismatches in social-ecological systems: causes, consequences, and solutions. Ecology and Society 11(1): 14. [online] URL: http://www.ecologyandsociety.org/vol11/iss 1/ art14/

Cundill, G., and C. Fabricius. 2010. Monitoring the governance dimension of natural resource co-management. Ecology and Society 15(1): 15. [online] URL: http://www.ecologyandsociety. org/vol15/iss1/art15/

Defeo, O., and A. de Alava. 1995. Effects of human activities on long-term trends in sandy beach populations: the wedge clam Donax hanleyanus in Uruguay. Marine Ecology Progress Series 123:73-82. http://dx.doi.org/10.3354/meps123073

Defeo, O., and J. C. Castilla. 1998. Harvesting and economic patterns in the artisanal Octopus mimus (Cephalopoda) fishery in a northern Chile cove. Fisheries Research 38:121-130. http://dx. doi.org/10.1016/S0165-7836(98)00155-6 
de la Torre-Castro, M., and L. Lindström. 2010. Fishing institutions: addressing regulative, normative and culturalcognitive elements to enhance fisheries management. Marine Policy 34:77-84. http://dx.doi.org/10.1016/j.marpol.2009.04.012

Dietz, T., E. Ostrom, and P. C. Stern. 2003. The struggle to govern the commons. Science 302:1907-1912. http://dx.doi.org/10.1126/ science. 1091015

Fernandez, M., E. Jaramillo, P. A. Marquet, C. A. Moreno, S. A. Navarrete, F. P. Ojeda, C. R. Valdovinos, and J. A. Vasquez. 2000. Diversity, dynamics and biogeography of Chilean benthic nearshore ecosystems: an overview and guidelines for conservation. Revista Chilena de Historia Natural 73:797-830. http://dx.doi.org/10.4067/S0716-078X2000000400021

Gelcich, S., G. Edwards-Jones, M. J. Kaiser, and J. C. Castilla. 2006. Co-management policy can reduce resilience in traditionally managed marine ecosystems. Ecosystems 9:951-966. http://dx.doi.org/10.1007/s10021-005-0007-8

Gelcich, S., T. P. Hughes, P. Olsson, C. Folke, O. Defeo, M. Fernández, S. Foale, L. H. Gunderson, C. Rodríguez-Sickert, M. Scheffer, R. S. Steneck, and J. C. Castilla. 2010. Navigating transformations in governance of Chilean marine coastal resources. Proceedings of the National Academy of Sciences of the United States of America 107:16794-16799. http://dx.doi. org/10.1073/pnas.1012021107

Grafton, R. Q., R. Arnason, T. Bjørndal, D. Campbell, H. F. Campbell, C. W. Clark, R. Connor, D. P. Dupont, R. Hannesson, R. Hilborn, J. E. Kirkley, T. Kompas, D. E. Lane, G. R. Munro, S. Pascoe, D. Squires, S. I. Steinshamn, B. R. Turris, and Q. Weninger. 2006. Incentive-based approaches to sustainable fisheries. Canadian Journal of Fisheries and Aquatic Sciences 63:699-710. http://dx.doi.org/10.1139/f05-247

Gutiérrez, N. L., R. Hilborn, and O. Defeo. 2011. Leadership, social capital and incentives promote successful fisheries. Nature 470:386-389. http://dx.doi.org/10.1038/nature09689

Hilborn, R., J. M. Orensanz, and A. M. Parma. $2005 a$. Institutions, incentives and the future of fisheries. Philosophical Transactions of the Royal Society B Biological Sciences 360:47-57. http://dx.doi.org/10.1098/rstb.2004.1569

Hilborn, R., J. K. Parrish, and K. Litle. 2005b. Fishing rights or fishing wrongs? Reviews in Fish Biology and Fisheries 15:191-199. http://dx.doi.org/10.1007/s11160-005-5138-7

Jentoft, S., and R. Chuenpagdee. 2009. Fisheries and coastal governance as a wicked problem. Marine Policy 33:553-560. http://dx.doi.org/10.1016/j.marpol.2008.12.002

Lebel, L., J. M. Anderies, B. Campbell, C. Folke, S. HatfieldDodds, T. P. Hughes, and J. Wilson. 2006. Governance and the capacity to manage resilience in regional social-ecological systems. Ecology and Society 11(1): 19. [online] URL: http://www. ecologyandsociety.org/vol11/iss1/art19/

Lima, M., A. Brazeiro, and O. Defeo. 2000. Population dynamics of the yellow clam Mesodesma mactroides: recruitment variability, density-dependence and stochastic processes. Marine Ecology Progress Series 207:97-108. http://dx.doi.org/10.3354/ $\underline{\text { meps } 207097}$
McLachlan, A., J. E. Dugan, O. Defeo, A. D. Ansell, D. M. Hubbard, E. Jaramillo, and P. E. Penchaszadeh. 1996. Beach clam fisheries. Pages 163-232 in A. D. Ansell, R. N. Gibson, and M. Barnes, editors. Oceanography and marine biology: an annual review. Volume 34. University College London Press, London, UK.

Meltzoff, S. K., Y. G. Lichtensztajn, and W. Stotz. 2002. Competing visions for marine tenure and co-management: genesis of a marine management area system in Chile. Coastal Management 30:85-99. http://dx.doi.org/10.1080/08920750252692634

Olivares, G. 2005. The role of semi-enclosed embayments for the metapopulation dynamics of coastal marine invertebrates in the Humboldt Current System. Dissertation. University of Bremen, Bremen, Germany.

Olsson, P., L. H. Gunderson, S. R. Carpenter, P. Ryan, L. Lebel, C. Folke, and C. S. Holling. 2006. Shooting the rapids: navigating transitions to adaptive governance of social-ecological systems. Ecological and Society 11(1): 18. http://www.ecologyandsociety. org/vol11/iss1/art18/

Orensanz, J. M., and G. S. Jamieson. 1998. The assessment and management of spatially structured stocks: an overview of the North Pacific Symposium on Invertebrate Stock Assessment and Management. Pages 441-459 in G. S. Jamieson and A. Campbell, editors. Proceedings of the North Pacific Symposium on Invertebrate Stock Assessment and Management. Canadian Special Publication of Fisheries and Aquatic Sciences 125. National Research Council of Canada, Ottawa, Ontario, Canada.

Orensanz, J. M. L., A. M. Parma, G. Jerez, N. Barahona, M. Montecinos, and I. Elias. 2005. What are the key elements for the sustainability of "S-fisheries"? Insights from South America. Bulletin of Marine Science 76:527-556. [online] URL: http://www. ingentaconnect.com/content/umrsmas/bullmar/2005/00000076/00000002/ $\underline{\operatorname{art} 00017}$

Ortega, L., J. C. Castilla, M. Espino, C. Yamashiro, and O. Defeo. 2012. Effects of fishing, market price, and climate on two South American clam species. Marine Ecology Progress Series 469:71-85. http://dx.doi.org/10.3354/meps10016

Ostrom, E. 2009. A general framework for analyzing sustainability of social-ecological systems. Science 325:419-422. http://dx.doi.org/10.1126/science.1172133

Pauly, D., V. Christensen, J. Dalsgaard, R. Froese, and F. Torres Jr. 1998. Fishing down marine food webs. Science 279:860-863. http://dx.doi.org/10.1126/science.279.5352.860

Pomeroy, R. S. 1995. Community-based and co-management institutions for sustainable coastal fisheries management in Southeast Asia. Ocean \& Coastal Management 27:143-162. http:// dx.doi.org/10.1016/0964-5691(95)00042-9

Riascos, J. M., D. Carstensen, J. Laudien, W. E. Arntz, M. E. Oliva, A. Güntner, and O. Heilmayer. 2009. Thriving and declining: climate variability shaping life-history and population persistence of Mesodesma donacium in the Humboldt Upwelling System. Marine Ecology Progress Series 385:151-163. http://dx. doi.org/10.3354/meps08042 
San Martín, G., A. M. Parma, and J. M. L. Orensanz. 2010. The Chilean experience with territorial use rights in fisheries. Page 324-337 in R. Q. Grafton, R. Hilborn, D. Squires, M. Tait, and M. Williams, editors. Handbook of marine fisheries conservation and management. Oxford University Press, New York, New York, USA.

Schumann, S. 2007. Co-management and "consciousness": fishers' assimilation of management principles in Chile. Marine Policy 31:101-111. http://dx.doi.org/10.1016/j.marpol.2006.05.008

Stotz, W. 1997. Las áreas de manejo en la Ley de Pesca y Acuicultura: primeras experiencias y evaluaciones de la utilidad de esta herramienta para el recurso loco. Estudios Oceanológicos 16:67-86.

Subsecretaría de Pesca y Acuicultura (SUBPESCA). 2013. Estado actual de las áreas de manejo. SUBPESCA, Valparaiso, Chile. [online] URL: http://www.subpesca.cl/institucional/602/w3article-5902.html

Thiel, M., E. C. Macaya, E. Acuña, W. E. Arntz, H. Bastias, K. Brokordt, P. A. Camus, J. C. Castilla, L. R. Castro, M. Cortés, C. P. Dumont, R. Escribano, M. Fernandez, J. A. Gajardo, C. F. Gaymer, I. Gomez, A. González, H. E. González, P. A. Haye, J.E. Illanes, J. L. Iriarte, D. A. Lancellotti, G. Luna-Jorquera, C. Luxoroi, P. H. Manriquez, V. Marín, P. Muñoz, S. A. Navarrete, E. Perez, E. Poulin, J. Sellanes, H. H. Sepúlveda, W. Stotz, F. Tala, A. Thomas, C. A. Vargas, J. A. Vasquez, and J. M. Vega. 2007. The Humboldt Current System of northern and central Chile: oceanographic processes, ecological interactions and socioeconomic feedback. Pages 195-344 in R. N. Gibson, R. J. A. Atkinson, and J. D. M. Gordon, editors. Oceanography and marine biology: an annual review. Volume 45. CRC, Boca Raton, Florida, USA. http://dx.doi.org/10.1201/9781420050943.ch6

Wilson, J. A. 2006. Matching social and ecological systems in complex ocean fisheries. Ecology and Society 11(1): 9. [online] URL: http://www.ecologyandsociety.org/vol11/iss1/art9/ 